\section{RAY TREATMENT OF RINGWORM.}

To the Editor of THE LANCET.

SIR,-I am of the opinion that the warning and recommendation of the Medical Defence Union (THE LANCET, Jan. 1st, p. 48) is an unnecessary one. In the first place, workers of $\mathrm{X}$ ray treatment for ringworm have already gone through the mill of prejudice and fear from parents who had heard of dire results, in days not long since passed, when the skeleton of "burnt heads" and "no hair" was put forward-with, undoubtedly, some reason-owing to unfortunate results obtained by early workers in producing permanent alopecias. Unfortunately, rumours of this kind are always exaggerated as they go from one parent to another. Some of the tales related by parents to me some six or seven years ago would have been sufficient, if really credited, to have produced hairraising results without the application of $X$ rays to both "operator" and "operated on."

At the present time I am happy to say that, after having treated over 800 cases without a single failure, it is now quite a different tale, and that parents may almost be said to be clamouring for $X$ ray treatment rather than go on for months with drug treatment. True, there are some cases, but a very small number, who from idiosyncrasy develop a definite reaction and suffer from erythema, or even a slight pustular eruption, as the result of $X$ ray application, but under appropriate remedies these quickly subside and the resulting growth of the hair is in no way retarded or diminished; in fact, I am of the opinion that as a result of the increased supply of blood during this period to the hair follicles, that the growth is often more rapid. Then why raise the voice of the general practitioner in warning parents against such trivial occurrences, or even raise the suspicion of the general practitioner himself, who, in most cases, is not cognisant of the pros and cons of the working of $\mathrm{X}$ ray treatment for ringworm?

800 cases means 4000 exposures, the carrying out of each exposure means a separate operation necessitating the maximum attention to detail. As Dr. W. Mitchell, of Bradford, says, the $X$ ray treatment of tinea tonsurans is the most exact and exacting form of treatment there is. I would go further and say it is also most tedious and monotonous, varied cnly by the extra burden of a fractious child. I work aiso with a small milliampèrage $(0.5 \mathrm{~m}$.a. $)$ with current 80 volts 5 amperes. In all cases the whole head is epilated by the Kienboch method with a light tungsten target tube, the five exposures being checked by Sabouraud and Noire's pastilles. After-treatment needs great care, and although Dr. C. W. Hutt considers it necessary in 1 out of 10, I make every child attend regularly for a fortnight to have the necessary stumps epilated by the school nurses to ensure that no form of infection is left. Some children are fit to return to school at the end of three weeks, the general average is, however, about 28 days.

In my opinion the essential points for success in the Kienboch method of treatment are to direct each irradiation at right angles to the direction of irradiation of adjacent areas and to aim not at a point in the centre of the vertex of the lower occiput or of the side of the scalp, but toward the outer margin of these areas, so that half the dose goes on to the scalp and half on to the shield protecting the face and the neck. If these precautions be taken there is no risk of over-exposure at the overlapping margins of the rayed areas. In practice the dosage works out so nicely that every part receives an equal amount and depilation is total and complete without anywhere a sign of over- or under-exposure.

The chief causes of failure are : (1) Under-exposure, so that an imperfect defluvium of the hair takes place and infected hairs are left; (2) omission of a focus of disease in the exposure; (3) insufficient thoroughness in the after-treatment. With recent methods of treatment and ordinary care there should be no failures.

I am, Sir, yours faithfully,

$$
\text { VICTOR J. BLAKE, M.B., B.S. Lond. }
$$

THE FINE CHEMICAL INDUSTRY.

To the Editor of THE LANCET.

SIR,-We, the undersigned, makers of fine chemicals, extended our research and manufacturing plant at the urgent appeal of the State during the tremendous years that followed 1914 in order to secure those essential products of science without which victory could not be attained. The full record of wartime achievements in the sphere of fine chemicals would read like a romance were the full history disclosed. This key industry is now endangered, and unemployment is rife in it, owing to the flood of imports from abroad which, among other circumstances, the present condition of the exchanges makes devastatingly possible.

We desire to submit to public knowledge the following acts :-

1. The application of chemical science to industry is a necessary factor for the preservation of our world position in commerce. It is also true to say not only that the chemist and the laboratory are in the first line of national defence, but are pivotal in the development of our industrial and commercial resources and wealth

2. At very considerable cost essential plant was erected during the war years, and all of it can now be put to peaceful purposes for the continuance in this country of a fine chemical industry not inferior to Germany's. But under the present unfair economic circumstances this plant must become idle and useless unless the State takes measures for its safeguarding.

3. The Fine Chemical Industry, mobilised and expanded in the hour of the nation's needs, provided during the warto give a few examples-(a) essential medicinal preparations for naval, military, and civilian hospitals; $(b)$ the higher forms of explosives and gases; (c) photographic chemicals for aerial use; $(d)$ research chemicals, without which the development of many new industrial processes would have been impossible.

4. British science is no whit inferior to that of competing nations, nor are British chemical manufactures inferior in quality

We feel it is our bounden public duty to make known to the country the national importance of an industry which is indeed a key to the unlocking of many doors of economic wealth in the future.

We are, Sir, yours faithfully,

STAFFord ALLEN AND SONS, Ltd.; A. BOAKE,

Roberts and Co., Lta.; BoOts PURe Drug Co.,

Ltd.; BRtTish CerluUtose and Chemical MFG.

Co., Ltd.; BRItish CyanIdes Co., Ltd.; BRITISH

Drug Houses, Ltd.; British Vegetable Pro-

DUCTs, Ltd. ; Burroughs, WELLCOME AND Co.;

W. J. Bush AND Co., Ltd.; J. M. ColletT AND Co., Lta.; Evans, SONs, LESCHER AND WEBB, Ltd.; GRAYS DYES AND CHEMICAL WORKS; HOPKIN AND WILlIAMs, Ltd.; Howards AND Sons, Lta.; Johnson and Sons, Mfg. Chemists,

Ltd.; LONDON CHEMICAL WORKS, Ltd.; MAY AND BAKER, Ltd.; THOS. MORSON AND SON, Ltd.; Pierson, Morreld AND Co., Lta. Feb. 19th, 1921

\section{THE OPERATIVE TREATMENT OF PROLAPSE.}

\section{To the Editor of THE LANCET.}

SIR,-In reply to Mr. J. P. Lockhart-Mummery's letter in your issue of Feb. 19th I did not advocate the use of "paraffin wax injections" in a general sense, but only the "submucous injection of paraffin wax," as described by me in THE LAANCET, 1904, vol. ii.. p. 759 . This may sound egotistical, but it is the attention to detail that makes all the difference. Consideration for your space will not permit me to reproduce the technique here, but the most essential points are that the parafin is injected into the submucous layer only at a temperature just above its melting point, so that it solidifies at once and does not travel, while the prolapse is still outside the anus, and so as to con stitute separate nodules arranged circumferentially around the rectum in definite tiers. With these precautions I fail to see how a "tunnel stricture" could result; probably in the case he mentions the wax had been introduced in too fluid a state and had completely surrounded the rectum in a continuous sheet. At any rate, I have never seen any sign of 